\title{
A new mid-Permian burnetiamorph therapsid from the Main Karoo Basin of South Africa and a phylogenetic review of Burnetiamorpha
}

Michael O. Day, Bruce S. Rubidge, and Fernando Abdala

Acta Palaeontologica Polonica 61 (4), 2016: 701-719 doi:https://doi.org/10.4202/app.00296.2016

Discoveries of burnetiamorph therapsids in the last decade and a half have increased their known diversity but they remain a minor constituent of middle-late Permian tetrapod faunas. In the Main Karoo Basin of South Africa, from where the clade is traditionally best known, specimens have been reported from all of the Permian biozones except the Eodicynodon and Pristerognathus assemblage zones.

Although the addition of new taxa has provided more evidence for burnetiamorph synapomorphies, phylogenetic hypotheses for the clade remain incongruent with their appearances in the stratigraphic column. Here we describe a new burnetiamorph specimen (BP/1/7098) from the Pristerognathus Assemblage Zone and review the phylogeny of the Burnetiamorpha through a comprehensive comparison of known material. Phylogenetic analysis suggests that BP/1/7098 is closely related to the Russian species Niuksenitia sukhonensis. Remarkably, the supposed mid-Permian burnetiids Bullacephalus and Pachydectes are not recovered as burnetiids and in most cases are not burnetiamorphs at all, instead representing an earlier-diverging clade of biarmosuchians that are characterised by their large size, dentigerous transverse process of the pterygoid and exclusion of the jugal from the lateral temporal fenestra. The evolution of pachyostosis therefore appears to have occurred independently in these genera. The resulting biarmosuchian tree is significantly more congruent with the stratigraphic appearance of its constituent taxa than in previous phylogenetic hypotheses and, consequently, does not necessarily constrain the diversification of the Burnetiamorpha to before the Capitanian.

Key words: Therapsida, Burnetiamorpha, Biarmosuchia, Karoo Basin, Poortjie Member, Capi ta nian extinction, South Africa.

Michael O. Day [michael.day@wits.ac.za], Bruce S. Rubidge [bruce.rubidge@wits.ac.za ], and Fernando Abdala [nestor.abdala@wits.ac.za], Evolutionary Studies Institute and School of Geoscience, University of the Witwatersrand, Johannesburg 2050, South Africa. 
This is an open-access article distributed under the terms of the Creative Commons

Attribution License (for details please see creativecommons.org), which permits unrestricted use, distribution, and reproduction in any medium, provided the original author and source are credited.

\author{
FoF Full text $(870.6 \mathrm{kB})$ । \\ FDF
}

